\title{
Importance of algal turf, grazers, and spatial variability in the recruitment of a subtidal colonial invertebrate
}

\author{
L. J. Stocker*, P. R. Bergquist \\ Leigh Marine Laboratory and Zoology Department, University of Auckland, New Zealand
}

\begin{abstract}
Factors affecting the recruitment of a colonial ascidian, Pseudodistoma novaezelandiae (Brewin), were investigated in a rocky subtidal habitat at Leigh, New Zealand. The presence of coralline algal turf enhanced recruitment both in natural conditions, when standardized against adult abundance, and also in an experiment in which algal turf was removed. Removal of the large gastropod Cookia sulcata (Gmelin) and the echinoid Evechinus chloroticus (Val.) had no effect on recruitment. Recruits were aggregated on 2 spatial scales, tens of metres and $\sim 1 \mathrm{~m}$; the degree of aggregation changed over the recruitment season, and varied according to the presence or absence of algal turf. Recruits occurred only in the vicinity of the highly localized populations of adult ascidians, separated by $100 \mathrm{~m}$ or more. Within these populations, however, on a scale of tens of metres, numbers of recruits were not correlated with adult abundance.
\end{abstract}

\section{INTRODUCTION}

Colonial ascidians occur extensively in marine, hardbottom habitats (Buss 1979, Russ 1980, Ayling 1981, Bak et al. 1981, Dean 1981, Grosberg 1981, Kay \& Keough 1981, Shin 1981, Connell \& Keough 1985, Sebens 1985) but, despite this prominence, few field experiments have focussed on factors affecting their distribution and abundance (Gulliksen \& Skjaeveland 1973, Schmidt \& Warner 1984, Olson 1985, Young 1985, Stocker \& Bergquist 1986). In particular, there is a conspicuous lack of information on recruitment of colonial ascidians (Russ 1980, van Duyl et al. 1981, Olson $1983,1985)$, although it is now widely recognised that early demographic processes may be important in determining patterns of adult abundance in sessile invertebrates (e.g. Grosberg 1982, Keough 1983, Underwood \& Denley 1984, Connell 1985, Gaines et al. 1985). This lack may be partially attributable to the generally low levels of recruitment of ascidians (Osman 1977, Keough 1983), making statistically powerful field experiments difficult.

Results from studies on a variety of invertebrates indicate that recruitment, and hence potentially the

\footnotetext{
- Present address: Zoology Building, School of Biological Sciences, University of Sydney, NSW 2006, Australia
}

distribution and abundance of populations, can be influenced by a host of factors. These include: physical disturbance (e.g. Osman 1977, Connell \& Keough 1985); predation (e.g. Day 1977, Russ 1980, Keough 1984); the presence of conspecifics (e.g. Young \& Braithwaite 1980, van Duyl et al. 1981, Schmidt 1982, Keough 1983, Benayahu \& Loya 1984, Jensen \& Morse 1984); and the presence of sessile xenospecifics. The latter can enhance recruitment by virtue of their physical structure (e.g. Russ 1980, Dean 1981, Keough \& Downes 1982, Eckman 1983, Schmidt 1983, Benayahu \& Loya 1984, Peterson 1986). In addition, the above factors may interact in complex ways (Russ 1980). Recruitment may also vary over many spatial scales (Keough \& Downes 1982, Keough, 1983, Caffey 1985 , Butler 1986), often depending on larval availability (Hawkins \& Hartnoll 1982, Kendall et al. 1982, Gaines et al. 1985, Connell 1985).

The present study describes the recruitment patterns of an abundant sessile invertebrate, the subtidal colo-

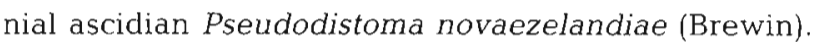
Numbers of recruits in areas where coralline algal turf was naturally present or absent were monitored to determine the distribution of recruits in space and time. A 3-factor experiment examined the effects of coralline algal turf and of grazing by invertebrates on recruitment, and measured spatial variability in recruitment. 
Throughout this paper, the term settlement is used to refer to attachment and metamorphosis of organisms, whereas recruitment refers to settlement together with any post-settlement mortality occurring until the time of observation (following Keough \& Downes 1982).

\section{MATERIALS AND METHODS}

Study sites. The work was done on the open coast at Leigh, New Zealand $\left(36^{\circ} 15^{\prime} \mathrm{S}, 174^{\circ} 48^{\prime} \mathrm{E}\right)$, on the northwestern side of Goat Island, at 2 sites: inner North Reef and D Buoy. North Reef is more exposed than D Buoy, but in other respects the sites are similar. They are $100 \mathrm{~m}$ apart in shallow water ( 3 to $6 \mathrm{~m}$ ), in an area of large sandstone boulders scattered over a greywacke bedrock. The large, herbivorous, grazing gastropod Cookia sulcata (Gmelin), the omnivorous sea urchin Evechinus chloroticus (Val.), and coralline algae, sometimes underlain by a layer of the barnacle Balanus trigonus Darwin, are abundant. Pseudodistoma novaezelandiae is a bright orange, gelatinous colonial ascidian attaining $15 \mathrm{~cm}$ diameter, with numerous mushroom-shaped lobes. It covers up to $20 \%$ of primary space at each site but varies seasonally in abundance (Stocker \& Bergquist 1986).

Natural populations. At D Buoy 20 permanent $1 \mathrm{~m}^{2}$ quadrats were established by marking the corners with plastic tags. Ten of these were on boulder-tops which had a low percent cover of coralline algal turf, and 10 were on flat areas among the boulders which had a high cover of algal turf (hereafter 'turf-flats'). The positions of the quadrats were not random; the quadrats were placed haphazardly where cover of Pseudodistoma novaezelandiae was $>10$ colonies $\mathrm{m}^{-2}(\sim 3 \%$ cover). At $6 \mathrm{wk}$ intervals numbers and sizes of all colonies, including recruits, in each permanent quadrat were recorded. Colony size was measured as the number of lobes in an adult colony.

Larvae are $\sim 3 \mathrm{~mm}$ in length (Stocker pers. obs.). Although settlement was not actually observed, we assume that newly metamorphosed individuals would be inmediately visible as recruits. The end of the recruitment phase for a colony was taken to be the time at which it began to develop a second lobe. Singlelobed recruits could contain up to 10 zooids, and were readily distinguished from other single-lobed (e.g. split or diseased) colonies by virtue of their delicate, transparent test with the orange pigment still rather pale.

Experiment. The experiment was done at North Reef. It tested the interactive effects of the presence of coralline algal turf and grazing invertebrates, and measured the spatial variability in recruitment of Pseudodistoma novaezelandiae among boulders.

Twenty boulders were chosen haphazardly from a population of flat-topped boulders $>2 \mathrm{~m}$ diameter and bearing Pseudodistoma novaezelandiae (mean $=9.1 \%$ cover, $\mathrm{SE}=5.6, \mathrm{n}=100 \mathrm{f}$. A $1 \mathrm{~m}^{2}$ plot was established on top of each boulder and 4 replicate settlement quadrats, $25 \times 25 \mathrm{~cm}^{2}$, were marked within the plots. The quadrats themselves contained no $P$. novaezelandiae colonies. An ancilliary test (Stocker 1986) confirmed field observations that large benthic feeding fish were not predators on $P$. novaezelandiae recruits; invertebrate grazers were the only agents of mortality considered. Half of the boulders had the natural density of invertebrates roaming over them: echinoids at a mean density of $8.8 \mathrm{~m}^{-2}$ $(\mathrm{SE}=5.6, \mathrm{n}=20)$ and Cookia sulcata at a mean density of $3.2(\mathrm{SE}=0.8, \mathrm{n}=20)$. We manually removed the invertebrates twice per week from the remaining boulders, because cages have proved so dubious in the degree to which they simulate the absence of predators in this (Stocker 1986) and other (Hulberg \& Oliver 1980, Schmidt \& Warner 1984) systems. This time interval was observed to be sufficiently small to keep the bouldertops free of grazers; the sides of the boulders acted as a buffer zone. On 5 of the boulders with urchins and on 5 without, all of the erect biota, which were mainly coralline algal turfs, were removed with a sledgehammer and a knife from the replicate quadrats. This treatment left a mosaic of bare rock and encrusting coralline algae, not unlike that found in natural situations in the same habitat. The remaining boulders were left completely untouched. Thus the factors Grazers and Algal Turf were orthogonal each with 2 fixed levels; Boulders was a random factor and nested within the interaction of Grazers $\times$ Algal turf. The number of recruits in each quadrat was counted at 6,12 , and $18 \mathrm{wk}$ after the experiment was established.

Spatial dispersion patterns of recruits were analysed in 2 ways. For the analysis of among-quadrat dispersion in the experiment, a mean density $(\bar{x})$ and a variance (s) were available for each boulder. We were therefore able to apply Taylor's method (Taylor 1961, Elliott 1971) in which $\log _{10} s^{2}$ is regressed on $\log _{10} \bar{x}$. The intercept of the regression line is related to the size of the sampling unit, and the slope of the line (regression coefficient) is an index of dispersion (Elliott 1971). A regression coefficient of 1 indicates that the population is dispersed randomly. A coefficient $<1$ indicates regular dispersion, and $>1$ indicates aggregation. Quadrats with no recruits were excluded from the analysis. Downing (1986) has recently pointed out that the regression coefficient can vary systematically with the number of samples taken and the ranges of means considered. To avoid the introduction of artefact, Downing suggested, coefficients should be compared only when similar levels of replication and ranges of means are used; these criteria were met in the present analysis.

Dispersion among boulders in the experiment and 
among permanent quadrats was described with Morisita's Index of Dispersion $\left(\mathrm{I}_{\delta}\right)$ (Morisita 1959, Taylor 1961):

$$
I_{\partial}=\frac{n\left[\left(\Sigma x^{2}\right)-\Sigma x\right]}{(\Sigma x)^{2}-\Sigma x}
$$

where $n=$ no. of sampling units (i.e. boulders or permanent quadrats; $\Sigma x=$ total no. of recruits in the sample. Quadrats with different numbers of recruits were commensurate because $I_{\delta}$ is independent of the sample mean and of the total numbers in the sample (Elliott 1971). Morisita's Index ranges between $1-[(n-1) /(\Sigma x-1)]$ for maximum regularity through 1 for random up to $\mathrm{n}$ for maximum contagion. Departures from randomness are significant when:

$$
\mathrm{I}_{\delta}(\Sigma \mathrm{x}-1)+\mathrm{n}-\Sigma \mathrm{x}
$$

is outside the appropriate significance levels of $\chi^{2}$ for n- 1 degrees of freedom (Elliott 1971).

Percent cover of adult colonies was measured with a $20 \times 20 \mathrm{~cm}$ quadrat strung to provide 20 intersections. It was laid haphazardly 10 times on each boulder.

\section{RESULTS}

\section{Natural populations}

In the permanent quadrats, recruits were first observed in October, and by April-May almost all the recruits had either died or had grown into 2-lobed juveniles. The number of recruits peaked slightly in November and then again in early March (Fig. 1a). Averaging across times, the number of recruits in turf-flat quadrats $(\vec{x}=4.68, \mathrm{SE}=1.33, \mathrm{n}=60$ ) was similar to the number of recruits in boulder-top quadrats $(\bar{x}=5.80$, $\mathrm{SE}=1.93, \mathrm{n}=60$ ). Relative to the number of adult lobes in a quadrat, however, recruitment was higher, especially early in the season, in turf-flat quadrats than in bouldertop quadrats (Fig. 1b). We chose to standardize recruitment against adult abundance because, given the very short larval duration of ascidians (Millar 1971), it is probable that larval supply is smaller on turf-flats where adult abundance is lower (Stocker \& Bergquist 1986).

Adult colonies were significantly clumped among quadrats (a scale of tens of metres) for both turf-flat $\left(\mathrm{I}_{\delta}=1.11, \chi^{2}=51.01, \mathrm{n}=10, \mathrm{p}<0.001\right)$ and bouldertop populations $\left(I_{\delta}=1.12, \chi^{2}=53.36, n=10, p<0.001\right)$. These figures probably underestimate the degree of aggregation because quadrats were not established in areas where there was no Pseudodistoma novaezelandiae. Except in one case, recruits were also significantly clumped among quadrats (Fig. 2), although for both the turf-flat and boulder-top quadrats, the degree of aggregation rose from October to January and
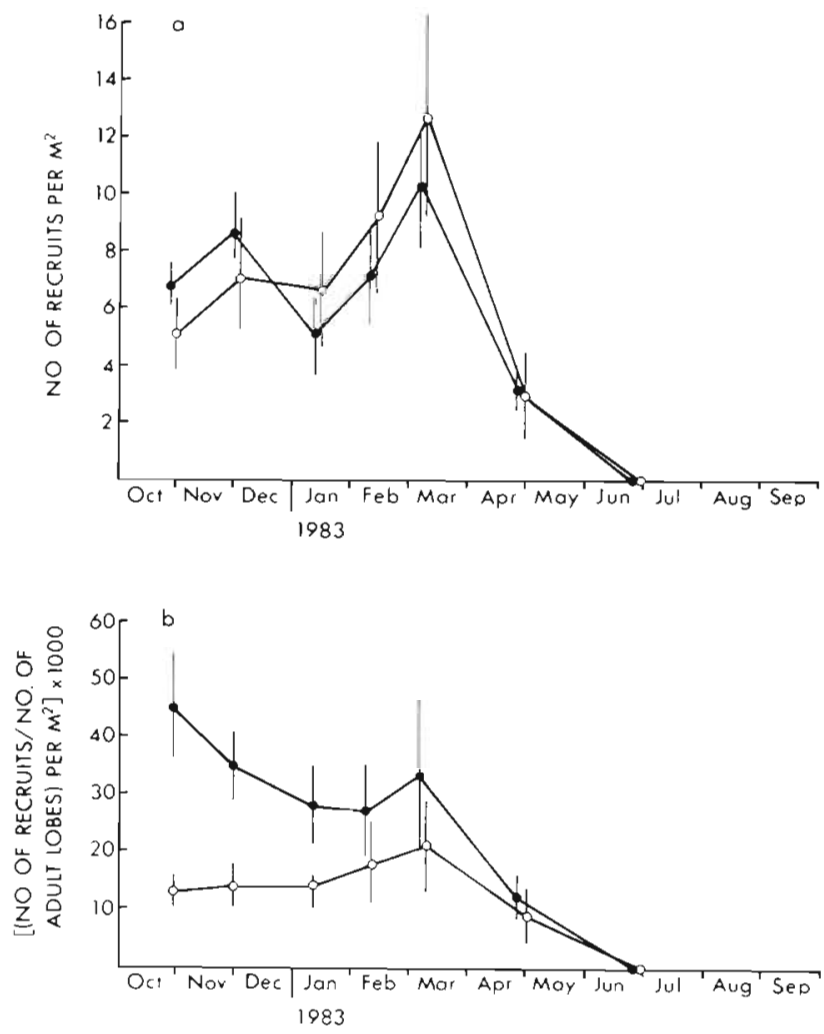

Fig. 1. Pseudodistoma novaezelandiae. (a) Numbers of recruits in the $1 \mathrm{~m}^{2}$ permanent quadrats in a natural population at $\mathrm{D}$ Buoy (mean $\pm S E$ ). (b) Number of recruits standardised against number of adult lobes [ (mean $\pm S E) \times 1000]$ in the permanent quadrats. (o) Boulder-tops; (•) turf-flats

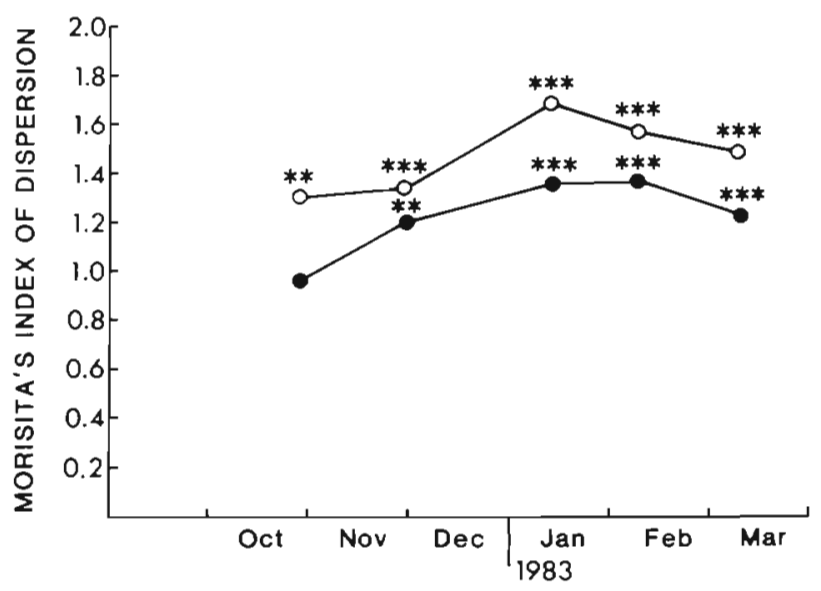

Fig. 2. Pseudodistoma novaezelandiae. Dispersion of recruits in the permanent quadrats in a natural population at $D$ Buoy. Asterisks indicate significant aggregation: ${ }^{* *} \mathrm{p}<0.01$; *** $p<0.001$. (ㅇ) Boulder-tops; $(\bullet)$ turf-flats

decreased from January to March (Fig. 2). Recruits were consistently more aggregated among boulder-top quadrats than among turf-flat quadrats. Using Pearson's coefficient on raw data, we found no significant correlations between the number of recruits and the 
area covered by adult colonies in permanent quadrats in any month, (all correlation coefficients ( $x$ ) lay between 0.13 and 0.17 ; and for all r's, $p>0.05$ and $n=20$ ).

On a scale of hundreds of metres to kilometres, populations of Pseudodistoma novaezelandiae are generally highly discrete, and no recruits were seen outside the areas where $P$. novaezelandiae occurred at high density, despite the apparent similarity and suitability of the surrounding habitat and the presence of a few adult colonies.

\section{Experiment}

Recruits were first observed in the experiment in October, 4 wk after it was established. Unfortunately, recruits were not actually counted for a further $2 \mathrm{wk}$ as rough seas had made the sampling unreliable.

The effect of Algal Turf was highly significant at all 3 sampling times, $6 \mathrm{wk}$ (October), $12 \mathrm{wk}$ (December), and $18 \mathrm{wk}$ (January) after the start of the experiment (Table 1). The removal of algal turf had reduced recruitment by one order of magnitude by October (Fig. 3). Some mortality and no observable recruitment occurred between the first and second times of sampling. Between the second and third times of sampling, the numbers of recruits increased in both treatments. The difference between the treatments with and without algal turf also increased over this period. Grazers had a non-significant effect at all 3 sampling times (Table 1), but there was significant variability among boulders at all 3 sampling times (Table 1).

There was no correlation between percent cover of adult Pseudodistoma novaezelandiae on a boulder and the number of recruits on a boulder $(r=0.2, n=20$, $\mathrm{p}>0.05$ ) at the end of the experiment

Dispersion among boulders was calculated for the + Algal Turf and - Algal Turf treatments numbers of recruits from the 4 replicate quadrats on each boulder were summed) (Fig. 4). There was no significant aggregation in either treatment in October, but by January recruits were aggregated among boulders in both treat-

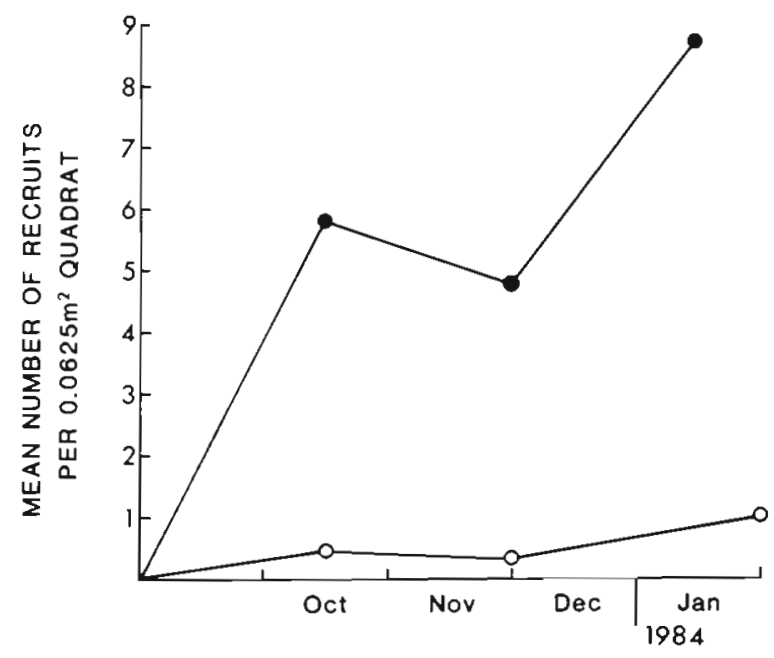

Fig. 3. Pseudodistoma novaezelandiae. Effect of the clearance of algal turf on recruitment at North Reef. (0) - Algal Turf $(\bullet)$ + Algal Turf

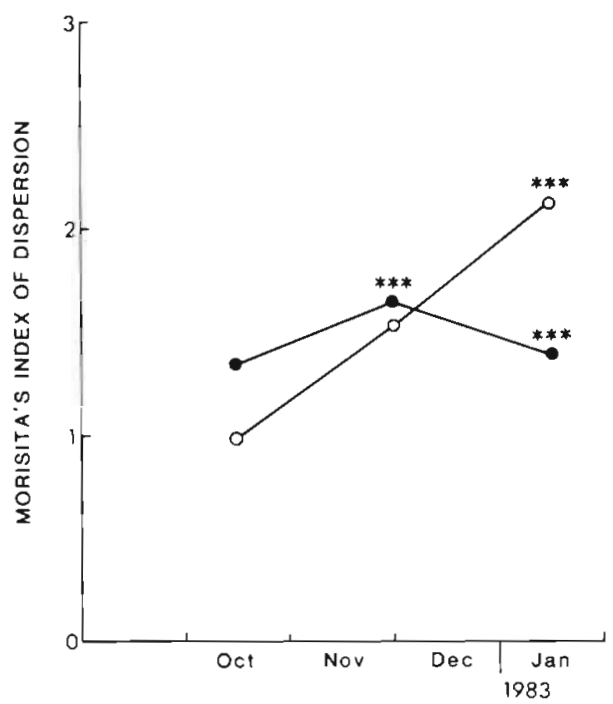

Fig. 4. Pseudodistoma novaezelandiae. Dispersion of recruits among boulders in the experiment at North Reef *** indicates significant aggregation, $\mathrm{p}<0.001 .(0)-$ Algal Turf; $(\bullet)+$ Algal Turf

Table 1. Pseudodistoma novaezelandiae. Analysis of variance tables for number of recruits in (a) October (b) December and (c) January. Data were $\ln (x+1)$ transformed to reduce heterogeneity in the variances $\cdot p<0.05 ; \cdots p<0.001 ;$ otherwise $p>0.05$. w.: nested within

\begin{tabular}{|c|c|c|c|c|c|c|c|}
\hline \multirow[t]{2}{*}{ Source of variation } & \multirow[t]{2}{*}{$\mathrm{df}$} & \multicolumn{2}{|c|}{ (a) October } & \multicolumn{2}{|c|}{ (b) December } & \multicolumn{2}{|c|}{ (c) January } \\
\hline & & MS & F & MS & F & MS & $\mathrm{F}$ \\
\hline $\operatorname{Turf}(\mathrm{T})$ & 1,16 & 33.8 & $48.5 \cdots$ & 30.8 & $39.6 \cdots$ & 39.9 & $26.5 \cdots$ \\
\hline Grazers (G) & 1,16 & 0.7 & 1.0 & 0.1 & 0.1 & 0.1 & 0.1 \\
\hline$T \times G$ & 1,16 & 0.7 & 1.0 & 1.7 & 2.2 & 0.8 & 0.5 \\
\hline Boulders $w .(T \times G)$ & 16,60 & 0.7 & $2.3^{\circ}$ & 0.8 & $2.1^{\circ}$ & 1.5 & $3.6^{\cdots}$ \\
\hline Residual & 60 & 0.3 & & 0.4 & & 0.4 & \\
\hline
\end{tabular}


ments. At this time, in each treatment there were boulders that differed in numbers of recruits by one order of magnitude or more.

The dispersion of recruits on a smaller spatial scale, i.e. among quadrats 0.5 to $1 \mathrm{~m}$ apart, was analysed by Taylor's method. The regression equations were $\log _{10}$ $s^{2}=\log _{10}(1.04)+1.446\left(\log _{10} \bar{x}\right)$ for October, $\log _{10} s^{2}=$ $\log _{10}(1.26)+1.520\left(\log _{10} \bar{x}\right)$ for December, and $\log _{10} \mathrm{~s}^{2}$ $=\log _{10}(1.40)+1.540\left(\log _{10} \overline{\mathrm{x}}\right)$ for January. The regression coefficient was significantly greater than 1 in October (t-test, $\mathrm{n}=19, \mathrm{p}<0.001$ ), December ( $\mathrm{t}$-test, $\mathrm{n}=16, \mathrm{p}<0.001$ ), and January (t-test, $\mathrm{n}=17$, $p<0.001$ ), indicating that recruits were strongly aggregated at all 3 sampling times (Fig. 5). None of the

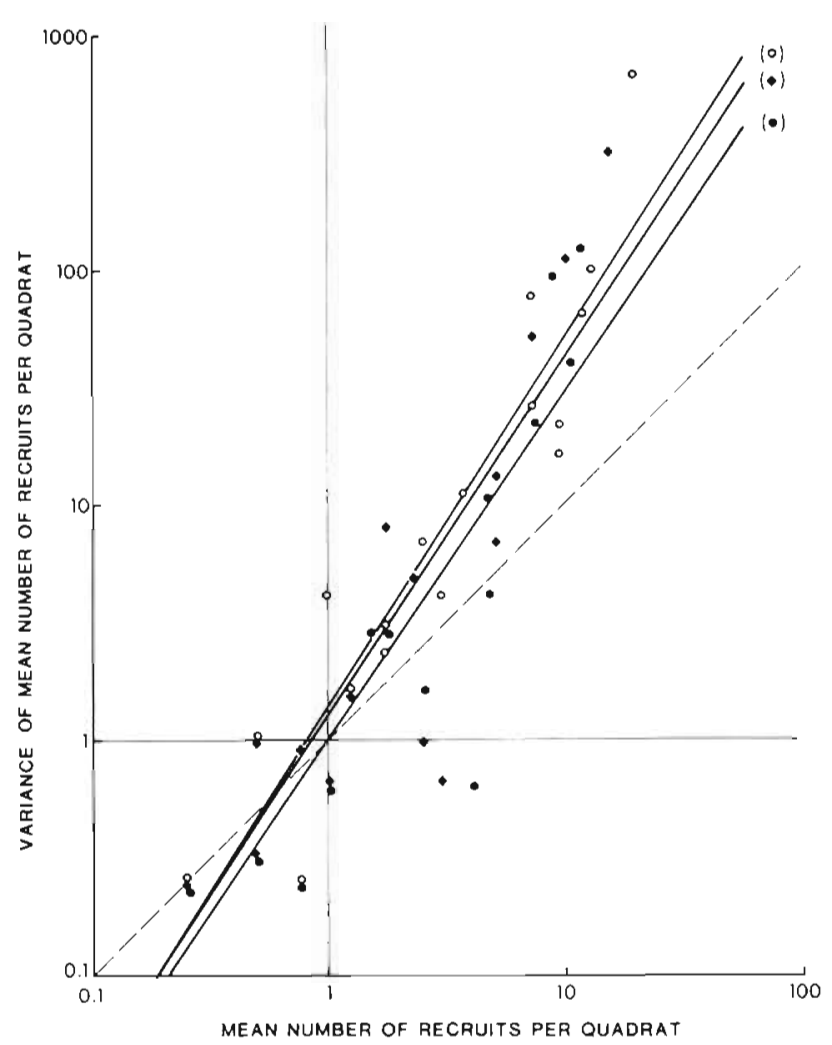

Fig. 5. Pseudodistoma novaezelandiae. Regression of variance against mean for numbers of recruits per $0.0625 \mathrm{~m}^{2}$ quadrat in the experiment at North Reef, plotted on $\log _{10}-\log _{10}$ axes. Dashed line indicates a slope of 1 , or random dispersion. See

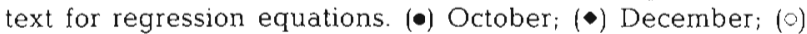
January

coefficients differed significantly from any other (Ftests, $p>0.05$ ). It can be seen that the relation between $\log _{10} \mathrm{~s}^{2}$ and $\log _{10} \overline{\mathrm{x}}$ is not strictly linear, as at high densities all points fall above the regression lines. Although this pattern is slight, it indicates a tendency for very strong aggregation at high densities relative to that at low densities.

\section{DISCUSSION}

Pseudodistoma novaezelandiae, like most colonial ascidians, settles in fairly low numbers compared to many solitary invertebrates like barnacles. Each successful ascidian recruit, however, can give rise to a large colony containing hundreds of individual zooids. The contribution that patterns of recruitment make to the distribution of the adult population is thus greatly amplified. Recruitment of $P$. novaezelandiae occurs at higher rates where coralline algal turf is present. This was found to be true for natural populations, when numbers of recruits were standardized against adult abundance, and also under experimental conditions in the field. In the experiment, the removal of algal turf from the rock decreased recruitment by one order of magnitude.

It has been suggested that settlers may be less accessible to predators on a complex substratum (Sutherland 1974, Russ 1980, Keough \& Downes 1982). Because grazers had no effect it seems more likely here that settlers on bare surfaces are dislodged by the water movement which is sometimes very great, especially at the North Reef site.

The greater recruitment in quadrats with algal turf may also be partly or wholly a result of differential settlement. Differential settlement may be due to purely passive responses of larvae to hydrodynamic patterns created by the complex nature of biota (Eckman 1983, Peterson 1986), or to the distribution of larvae in the water column (e.g. Keough 1983, Gaines et al. 1985). Differential settlement may also result from active preference of larvae for a particular substratumtype; the proximal cue may be chemical (Davis 1987), or a quality afforded by the physical complexity of biota such as darkness or a more secure attachment (Dean 1981, Schmidt 1983, Benayahu \& Loya 1984). The best evidence of larval preference is direct observation of settlement itself (Olson 1983, 1985, Davis 1987).

Either passive differential settlement or active preferential settlement would enhance survivorship of adult colonies of Pseudodistoma novaezelandiae if and only if the effects of coralline algal turf on $P$. novaezelandiae, and the spatial relationship between the two, were consistent over the several-year life-span of an ascidian colony. Although we have no information on the latter criterion, we know that the effect of algal turf on adult $P$. novaezelandiae varies according to the size of the colony (Stocker \& Bergquist 1986). Small colonies can be overgrown by algal turf, especially if water movement is low, and this interaction may contribute to the low adult abundance of $P$. novaezelandiae on the turf-flats at $\mathrm{D}$ Buoy. Colonies can also be protected from being torn up at the edges by the presence of algal turf in conditions of high water movement. We con- 
clude that recruitment is increased in the presence of algal turf. Also, the presence of algal turf can favour survivorship in adult colonies by virtue of physical protection, but only if they can avoid being overgrown when small.

Spatial variability in recruitment in sessile invertebrates has rarely been quantified in the field on more than one scale (Keough 1983, Caffey 1985). Pseudodistoma novaezelandiae recruits were observed to be associated with high densities of adults on a scale of hundreds of metres to kilometres. The duration of the larval phase in most ascidians is only a few minutes (Millar 1971, Olson 1983) and it seems appropriate to argue that if this is also true for $P$. novaezelandiae then we need not inyoke differential survivorship or even gregarious settlement to explain this broad-scale (hundreds of metres) association between adults and recruits. On a scale of tens of metres, however, there was no correlation between the density of adults and recruits, indicating that recruitment was not affected by the proximity of adults.

Pseudodistoma novaezelandiae recruits themselves tended to the clumped on a scale of tens of metres, although early in the recruitment season their distribution was close to random. This was true for recruits recorded both in the $1 \mathrm{~m}^{2}$ permanent quadrats and in the $1 \mathrm{~m}^{2}$ experimental plots on the tops of boulders in the experiment. In the experiment, the aggregation measured among boulders became more accentuated between the first and second sampling times. As there was no recruitment during this time, it is apparent that dispersion of the pre-existing recruits was affected by differential survival. We suggest that the pattern of spatial dispersion of recruits may be responsible for the distribution of adult colonies, which were aggregated on the same scale as the recruits.

On a smaller spatial scale, i.e. 0.5 to $1 \mathrm{~m}$, recruits were also clumped, and to a greater degree at high densities than at low densities. This highly aggregative relationship among recruits may indicate that most larvae travel as a group in the plankton, that the number of larvae settling in a quadrat is positively correlated with the number already there, or that the majority of larvae are stimulated to settle by the same environmental cues. As mentioned above, there also exist the possibilities that there is a negative relationship between mortality and density or that differential mortality associated with other environmental factors is occurring. The manipulation of the density and dispersion of recruits and the monitoring of survivorship of individuals will be required to distinguish among these numerous models

Acknowledgements. We thank N. L. Andrew, G. P. Jones, U. L. Kaly, M. J. Kingsford, A. B. MacDiarmid, K. A. McGuinness, B. D. Mapstone, S. Mullin., M. A. O'Donnell, and A. J.
Underwood for criticising and improving the manuscript in its numerous forms. The manuscript also benefitted from the suggestions of 2 anonymous reviewers. We are grateful to A. McCrone for her able assistance in the field and to people at the Leigh Marine Laboratory for technical support and profitable discussion.

\section{LITERATURE CITED}

Ayling, A. M. (1981). The role of biological disturbance in temperate, subtidal encrusting communities. Ecology 62: 830-847

Bak, R. P. M., Sybesma, J., Duyl, F. C. van (1981). The ecology of the tropical compound ascidian Trididemnum solidum II. Abundance, growth and survival. Mar Ecol. Prog Ser. 6: 43-52

Benayahu, Y., Loya, Y. (1984). Substratum preferences of two red sea alcyoneans: Xenia macrospiculata Gohar and Parerythropodium fulvum (Forskal). J. exp. mar. Biol. Ecol. 83: $249-261$

Buss, L. W (1979). Habitat selection, directional growth and spatial refuges: why colonial animals have more hiding places. In: Larwood, G., Rosen, B. (ed.) Biology and systematics of colonial organisms. Academic Press, New York, p. 459-497

Butler, A. J. (1986). Recruitment of sessile invertebrates at five sites in Gulf St. Vincent, South Australia. J. exp. mar. Biol. Ecol. 97: 13-36

Caffey, H. M. (1985). Spatial and temporal variation in settlement and recruitment of intertidal barnacles. Ecol. Monogr. 55: 313-332

Connell, J. H. (1985). The consequences of variation in initial settlement vs. post-settlement mortality in rocky intertidal communities. J. exp. mar. Biol. Ecol. 93: 11-45

Connell, J. H., Keough, M. J. (1985). Disturbance and patch dynamics of subtidal marine animals on hard substrata. In: Pickett, S. T A., White, P. S. (ed.) The ecology of natural disturbance and patch dynamics. Academic Press, New York, p. 125-151

Davis, A. R. (1987). Variation in recruitment of the subtidal colonial ascidian Podoclavella cylindrica (Quoy \& Gaimard): the role of substratum choice and early survival. J. exp. mar. Biol. Ecol. 106: 57-71

Day, R. W (1977). Two contrasting effects of predation on species richness in coral reef habitats. Mar Biol. 44:1-5

Dean, T. A. (1981). Structural aspects of sessile invertebrates as organising forces in an estuarine fouling community. J. exp. mar. Biol. Ecol. 53: 163-180

Downing, J. A. (1986). Spatial heterogeneity: evolved behaviour or mathematical artefact? Nature, Lond. 323: $255-257$

Duyl, F. C. van, Bak, R. P. M. Sybesma, J. (1981). The ecology of the tropical compound ascidian Trididemnum solidum I Reproductive strategy and larval behaviour. Mar. Ecol. Prog. Ser 6: 35-42

Eckman, J. E. (1983). Hydrodynamic processes affecting benthic recruitment. Limnol. Oceanogr. 28: 241--257

Elliott, J. M. (1971). Some methods for the statistical analysis of samples of benthic invertebrates. Freshwater Biological Association, Scientific Publication No. 25, Ferry House

Gaines, S., Brown, S., Roughgarden, J. (1985). Spatial variation in larval concentration as a cause of spatial variation in settlement for the barnacle, Balanus glandula. Oecologia (Berl.) 67. 267-272

Grosberg, R. K. (1981). Competitive ability influences habitat choice in marine invertebrates. Nature, Lond. 290: 700-702 
Grosberg, R. K. (1982). Intertidal zonation of barnacles: the influence of planktonic zonation of larvae on vertical distribution of adults. Ecology 63: 894-899

Gulliksen, B., Skjaeveland, S. H. (1973). The seastar Asterias rubens (L.) as predator on the ascidian Ciona intestinalis (L.) in Borgenfjorden, North-Trondelag, Norway. Sarsia 52: $15-20$

Hawkins, S. J., Hartnoll, R. G. (1982). Settlement patterns of Semibalanus balanoides (L.) in the isle of Man (1977-1981). J. exp. mar Biol. Ecol. 62: 271-283

Hulberg, L. W., Oliver, J. S. (1980). Caging manipulations in marine soft-bottom communities: importance of animal interactions or sedimentary habitat modifications. Can. J. Fish. Aquat. Sci. 37: 1130-1139

Jensen, R. A., Morse, D. E. (1984). Intraspecific facilitation of larval recruitment: gregarious settlement of the polychaete Phragmatopoma californica (Fewkes). J. exp. mar. Biol. Ecol. 83: 107-126

Kay, A. M., Keough, M. J. (1981). Occupation of patches in the epifaunal communities on pier pilings and the bivalve Pinna bicolor at Edithburgh, South Australia. Oecologia (Berl.) 48: 123-130

Kendall, M. A., Bowman, R. S., Williamson, P., Lewis, J. R (1982). Settlement patterns, density and stability in the barnacle Balanus balanoides. Neth. J. Sea Res. 16: $119-126$

Keough, M. J. (1983). Patterns of recruitment of sessile invertebrates in two subtidal habitats. J. exp. mar. Biol. Ecol. 66: 213-245

Keough, M. J. (1984). Dynamics of the epifauna of the bivalve Pinna bicolor: interactions among recruitment, predation and competition. Ecology 65: 677-688

Keough, M. J., Downes, B. J. (1982). Recruitment of marine invertebrates: the role of active larval choices and early mortality. Oecologia (Berl.) 54: 348-352

Millar, R. H. (1971). The biology of ascidians. Adv. mar. Biol. 9: $1-100$

Morisita, M. (1959). Measuring dispersion of individuals and analysis of the distributional patterns. Mem. Fac. Sci. Kyushu Univ. Ser E. Biol. 2: 215-235

Olson, R. R. (1983). Ascidian-Prochloron symbiosis. The role of larval photoadaptations in midday larval release and settlement. Biol. Bull. mar biol. Lab., Woods Hole 165 221-240

Olson, R. R. (1985). The consequences of short-distance larval dispersal in a sessile marine invertebrate. Ecology 66 30-39

Osman, R. W. (1977). The establishment and development of a marine epifaunal community. Ecol. Monogr. 47 37-63
Peterson, C. H. (1986). Enhancement of Mercenaria mercenaria densities in seagrass beds: is pattern fixed during settlement season or altered by subsequent differential survival? Limnol. Oceanogr. 31 200-205

Russ, G. R. (1980). Effects of predation by fishes, competition, and structural complexity of the substratum on the establishment of a marine epifaunal community. J. exp. mar Biol. Ecol. 42: 55-69

Schmidt, G. H. (1982). Random and aggregative settlement in some sessile marine invertebrates. Mar. Ecol. Prog. Ser. 9 $97-100$

Schmidt, G. H. (1983). The hydroid Tubularia larynx causing a 'bloom' of the ascidians Ciona intestinalis and Ascidiella adspersa. Mar Ecol. Prog. Ser. 12: 103-105

Schmidt, G. H., Warner, G. F. (1984). Effects of caging on the development of a sessile epifaunal community. Mar. Ecol. Prog. Ser. 15: 251-263

Sebens, K. P. (1985). Community ecology of vertical rock walls in the gulf of Maine, USA: small-scale processes and alternative community states. In: Moore, P. G., Seed, R (ed.) The ecology of rocky coasts. Hodder \& Stoughton, London, p. 346-371

Shin, P. K. S. (1981). The development of sessile epifaunal communities in Kylesalia Killcieran Bay (West Coast of Ireland). J. exp. mar. Biol. Ecol. 54: 97-111

Stocker, L. J. (1986). Artifactual effects of caging on the recruitment and survivorship of a subtidal colonial invertebrate. Mar. Ecol. Prog. Ser 34: 305-307

Stocker, L. J., Bergquist, P. R. (1986). Seasonal cycles, extrinsic factors, and the variable effects of turfing algae on the abundance of a colonial ascidian. J. exp. mar. Biol. Ecol. 102: $1-21$

Sutherland, J. P. (1974). Multiple stable points in natural communities. Am. Nat. 108: 859-873

Taylor, L. R. (1961). Aggregation, variance and the mean. Nature, Lond. 189: 732-735

Underwood, A. J., Denley, E. J. (1984). Paradigms, explanations, and generalizations in models for the structure of intertidal communities on rocky shores. In: Strong, D. R. Simberloff, D., Abele, L. G., Thistle, A. B. (ed.) Ecological communities: conceptual issues and the evidence. Princeton Univ. Press, Princeton, p. 151-180

Young, C. M. (1985). Abundance patterns of subtidal solitary ascidians in the San Juan Islands, Washington, as influenced by food preferences of the predatory snail Fusitriton oregonensis. Mar. Biol. 84: 309-321

Young, C. M., Braithwaite, L. F. (1980). Larval behaviour and post-settling morphology in the ascidian Chelysoma productum Stimpson. J. exp. mar. Biol. Ecol. 42: 157-169 